\title{
Self-concept dan Family Support dengan Academic Burnout pada Siswa di Masa Pandemi
}

\section{Self-Concept and Family Support on Student's Academic Burnout During Pandemic}

\author{
Puput Rista Diyanti ${ }^{1 *}$ \\ Universitas Islam Negeri Sunan Ampel \\ *puputristadiyanti@gmail.com
}

\begin{abstract}
Abstrak
Tujuan penelitian adalah untuk mengetahui hubungan antara self-concept dan family support dengan academic burnout pada siswa MI Darussalam di masa pandemic secara parsial dan simultan. Penelitian ini merupakan penelitian kuantitatif korelasional. Subjek pada penelitian ini adalah siswa-MI Darussalam. Jumlah sampel dalam penelitian ini sebanyak 72 siswa kelas dari 266 siswa MI Darussalam dengan teknik probability sampling. Dari populasi tersebu ditetapkan sebanyak 72 siswa dari kelas 4,5,6. Dari hasil penelitian diketahui bahwa self-concept secara signifikan berhubungan negative dengan academic burnout. Kedua, Family support secara signifikan berhubungan negative dengan academic burnout. Ketiga, self-concept dan family support secara signifikan berhubungan negative dengan academic burnout.
\end{abstract}

Kata kunci : Self-concept, family support, academic burnout

\begin{abstract}
The study purpose was to determine the relationship between self-concept and family support with academic burnout of student's at MI Darussalam during the pandemic period partially and simultaneously. This research is a quantitative correlational research. The subjects were students of MI Darussalam. The number of samples in this study were 72 students from 266 students of MI Darussalam with probability sampling technique. From this population, the researchers took 72 students from grades 4,5,6. From the results of the study, it is known that self-concept is significantly negatively related to academic burnout. Family support is significantly negatively related to academic burnout. Third, self-concept and family support are significantly negatively related to academic burnout
\end{abstract}

Keywords : self-concept, family support, academic burnout

\section{Pendahuluan}

Dalam masa pandemic Covid 19 ini, pembelajaran dilakukan dengan kegiatan belajar dirumah secara online (daring), berdasarkan Surat Edaran No. 4 Tahun 2020 tentang Pelaksanaan Kebijakan Pendidikan Masa Darurat Penyebaran Corona Virus Disease (Covid-19). Dalam kegiatan pembelajaran daring, siswa dan guru tidak dapat berinteraksi secara langsung dengan tatap muka. Pembelajaran dilakukan dengan media online yang memiliki banyak keterbatasan.

Beberapa siswa diketahui mengalami kesulitan dalam beradaptasi dengan pembelajaran daring. Menurut Purwanto, et.al (2020) kendala yang dihadapi orang tua, siswa, dan guru dalam pembelajaran daring diantaranya : minimnya penguasaan teknologi, keterbatasan kuota, aktivitas tambahan orang tua dalam mendampingi kegiatan belajar anak, berkurangnya komunikasi dan sosialisasi, dan jam kerja guru yang menjadi tidak terbatas.

Siswa yang mengalami kesulitan dalam beradaptasi dengan pembelajaran daring, dapat mengalami 
burnout academic dan berpotensi mengganggu capaian belajarnya ditandai dengan performa yang menurun dalam akademik (Asrowi, dkk: 2020). Penelitian oleh Asrowi di eks-karisidenan Surakarta ini menunjukkan bahwa 50\% siswa mengalami academic burnout pada kategori sedang, dan 10\% tergolong tinggi, sehingga penting untuk diperhatikan.

Sebagai muslim, sejatinya, kelelahan dalam menuntut ilmu adalah bagian dari perjuangan yang bernilai. Keutamaan dalam menuntut ilmu dijelaskan dalam surah Ali-Imran Ayat 79 Allah S.W.T berfirman :

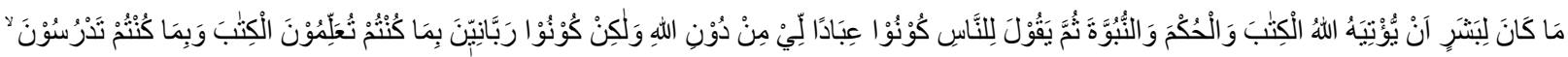

Artinya:

Tidak mungkin bagi seseorang yang telah diberi kitab oleh Allah, serta hikmah dan kenabian, kemudian dia berkata kepada manusia, "Jadilah kamu penyembahku, bukan penyembah Allah," tetapi (dia berkata), "Jadilah kamu pengabdi-pengabdi Allah, karena kamu mengajarkan kitab dan karena kamu mempelajarinya!".

Ayat tersebut menunjukkan keutamaan dalam menuntut ilmu/ belajar sehingga penting bagi kita untuk menghindari dan menyelesaikan permasalahan yang dialami dalam menuntut ilmu, termasuk pentingnya mengatasi academic burnout. Dalam rangka upaya mengatasi hambatan atau permasalahan pembelajaran saat ini dengan melakukan penelitian dan pengembangan ilmu pengetahuan tentang pembelajaran, maka penting untuk melakukan penelitian tentang academic burnout ini.

Dari studi pendahuluan pada siswa MI Darussalam melalui penyebaran angket secara secara online dengan google-form, diketahui bahwa $78,4 \%$ siswa mengalami kelelahan selama pembelajaran daring, $62,2 \%$ siswa merasa kesal karena banyaknya tugas selama pembelajaran daring, dan $78,4 \%$ siswa merasa tidak dapat menangkap dengan baik materi pelajaran yang diberikan guru selama pembelajaran daring. Melalui hasil survey ini, diketahu bahwa siswa cenderung mengalami kelelahan akademik atau academic burnout. Hal ini dikuatkan dengan hasil wawancara lebih lanjut terhadap siswa MI Darussalam, hal yang dikeluhkan oleh siswa adalah tugas yang dirasakan terlalu banyak sehingga membebani, siswa merasa bosan dengan metode balajar yang diterapkan, dan materi yang sulit dipahami

Fraudenberger (1974) yang pertama kali memperkenalkan, menggambarkan burnout sebagai sindrom kelelahan yang dialami oleh tenaga kesehatan saat itu. Fraudenberger menjelaskan bahwa burnout adalah kondisi kelelahan yang dialami individu, secara fisik, mental dan juga emosional yang disebabkan oleh ketidakseimbangan antara kondisi individu dengan tuntutan pekerjaan atau tugasnya. Burnout adalah respon yang berkepanjangan atas stressor yang terus-menerus yang teerjadi di empat kerjanya yang hasilnya merupakan perpadual antara pekerja dan pekerjaaanya (Papalia, 2007).

Burnout pada awalnya digunakan dalam setting pekerjaan, namun kemudian berkembang sehingga juga dikaji dalam setting akademik (Maslach et.al: 2006). Meski tidak dalam aktivitas sebagai pekerjaan, namun aktivitas belajar siswa dengan berbagai dinamikanya memungkinkan siswa mengalami kondisi burnout ini.

Dalam pembelajaran atau aktivitas akademik, burnout disebut dengan istilah academic burnout, school burnout, dan student burnout. Schaufeli et.al. (2002) mendefinisikan academic burnout sebagai suatu kondisi dimana siswa mengalami kelelahan akibat tuntutan atau tugas akademik sehingga memunculkan sikap yang sinis, pesimis dan ditandai menurunya minat siswa dalam menjalankan proses pendidikan. Academic burnout juga didefinisikan sebagi kondisi siswa yang secara fisikm mengalami penurunan daya dan kurang berenergi, serta mengalami penurunan secara psikologis sehingga ia kehilangan keinginan untuk belajar (Welong, et.al, 2020). Hederich\& Caballero (2016) mendefinisikan academic burnout sebagai perasaan tidak mampu yang dialami siswa untuk menjalani proses akademik secara optimal, sehingga memunculkan sikap yang negative, diantaranya kritik, devaluasi, dan hilangnya minat serta motivasi untuk menyelesaikan tugas-tugasnya. Dalam penelitian ini, academic burnout didefinisikan sebagai kondisi psikologis yang dialami siswa dalam lingkungan akademik, dimana secara fisik dan psikologis merasa lelah, hilangnya motivasi siswa, dan bersikap sinis akan hal yang berhubungan dengan kegiatan akademik, sehingga menyebabkan pencapaian individu tersebut menurun.

Menurut Schaufeli (2002), academic burnout terdiri atas 3 dimensi. Pertama dimensi exhaustion yang mengarah pada kondisi perasaan lelah secara emosional. Kedua, dimensi cynicism yang mengacu pada sikap acuh dalam proses pembelajaran. Ketiga, reduce of Professional Efficacy yang mengarah pada kondisi perasaan bahwa tidak sanggup akan tugas-tugas selama proses pembelajaran. Akibatnya, siswa yang mengalami academic burnout akan menunjukkan perubahan sikap dalam belajar, cenderung 
menarik diri, dan merasa dirinya tidak mampu dalam mengemban tugas yang diberikan.

Disamping berdampak pada prestasi belajar siswa, academic burnout juga dapat menyebaban masalah psikologis lainnya. Academic burnout yang dialami siswa dalam masa pandemic ini mengacu pada stress dan beban akademik (Yang, 2004). Yang menambahkan bahwa academic burnout dapat menyebabkan siswa mengalami berbagai tekanan mental seperti kecemasan, depresi, frustasi, ketakutan. Tsigilis \& Koustelios (2011) menyebutkan bahwa dampak academic burnout pada siswa diantaranya, menurunnya motivasi, adanya perasaan ditolak oleh lingkungannya, kepuasannya cenderung rendah, dan timbulnya perasaan gagal.

Terdapat beberapa faktor yang berpotensi menyebabkan seseorang mengalami academic burnout, yaitu faktor internal tetapi juga faktor eksternal (Maslach et al, 1997). Dalam penelitian ini, peneliti ingin menguji self-concept sebagai faktor internal dalam hubungannya dengan academic burnout siswa. Dari penelitian Wang et al (2019) pada mahasiswa keperawatan, diketahui bahwa secara signifikan terdapat hubungan antara self-concept dengan academic burnout.

Menurut Dalimunthe (2020) self-concept adalah segala rasa mengenai diri sendiri sebagai individu dan diyakini sebagai kebenaran. Self-concept dapat mempengaruhi proses berpikir individu, perasaannya, keinginannya, dan nilai maupun tujuan hidupnya. Self-concept akan mempengaruhi beberhasilan siswa.

Dalam setting akademik, Hattie (dalam Khafiya 2018), mendefinisikan academic self-concept sebagai sebagai penilaian individu yang terkait dengan aktivitas di dalam kelas atau di sekolah yang berhubugan dengan persepsi, pikiran, perasaan dan penilaian seseorang tentang kemampuan akademiknya, kemampuannya untuk mengikuti pembelajaran, dan kemampuannya untuk meraih prestasi tertentu dalam bidang akademis. Hattie menyebut 3 komponen self-concept akademik; yaitu (1) classroom self concept dimana terkait dengan bagaimana siswa membandingkan dirinya dengan temantemannya di kelas, (2) ability self concept, yang menunjukkan pada konsep diri siswa tentang kemampuan akademiknya, dan (3) achievement self concept, yang berhubungan dengan prestasi aktual akademik siswa.

Selain factor internal, self-concept juga dipengaruhi oleh factor eksternal ((Maslach et al, 1997). Dalam pembelajaran daring, peran keluarga bertambah, dimana orangtua dapat menjadi guru dan pengawas bagi anaknya (Sari, 2020). Salah satu bentuk dukungan sosial adalah family support sebaga bagian dari faktor eksternal yang dimungkinkan dapat mempengaruhi academic burnout.

Family support adalah dukungan oleh anggota keluarga, yang dapat berupa pengorbanan, dorongan, semangat, dan nasihat sehingga individu kemudian merasa bahwa ia memiliki tumpuan harapan, tempat untuk dapat bercerita, dan tempat untuk berkeluh kesah ketika menghadapi permasalahan (Irwanto dalam Anggriana et al 2014). Family support dapat memberikan perasaan nyaman pada siswa, secara fisik dan secara emosional (Anggriana et al, 2014). Menurut Kim et al (2018), family support dapat meminimalisir kemungkinan terjadinya academic burnout yang dialami siswa

Berdasarkan uraian latar belakang diatas, diketahui pentingnya penelitian tentang factor dapat yang mempengaruhi academic burnout siswa dalam pembelajaran daring di masa pandemi ini, dan peluang menguji hubungan antara variabel self-concept dan variabel family support dengan academic burnout siswa. Penelitian ini ditujukan untuk mengetahui apakah terdapat hubungan variabel selfconcept dan family support dengan academic burnout siswa secara parsial dan simultan.

\section{Metode Penelitian}

Penelitian ini adalah penelitian kuantitatif korelasional yang akan menguji pengaruh variabel selfconcept (X1) dan family support (X2) terhadap academic burnout $(\mathrm{Y})$ pada siswa MI Darussalam, secara parsial dan simultan. Populasi dari penelitian ini sebanyak 266 siswa MI Darussalam. Dengan teknik probability sampling, ditentukan sampel sejumlah 72 siswa di kelas 4, kelas 5, dan kelas 6 .

Teknik pengumpulan data dilakukan dengan penyebaran kuesioner/angket dengan skala Lickert yaitu skala academic burnout, skala self-concept, dan skala family support. Instrumen yang digunakan merupakan hasil modifikasi instrumen dari beberapa peneliti terdahulu, dan telah dilakukan uji validitas dengan pearson-correlation sehingga diperolah 34 aitem valid. Uji reliabilitas dengan crobach alpha sehingga diketahui instrument yang digunakan tersebut valid dan reliabel.

Uji prasyarat yang dilakukan sebelum melakukan uji hipotesis, meliputi uji normalitas dan uji linieritas. Analisis data dengan analisis product momen pearson dan korelasi berganda. 


\section{Hasil Penelitian}

Subjek dalam penelitian ini adalah 72 siswa MI Darussalam. Dari 72 siswa tersebut, 32 siswa dengan jenis kelamin laki laki dan selebihnya, terdapat 40 siswa dengan jenis kelamin perempuan. Sebarannya diketahui sebagai berikut:

Tabel 1. Deskripsi Siswa Berdasarkan Jenis Kelamin

\begin{tabular}{ccc}
\hline & Frekuensi & Presentase (\%) \\
\hline Laki-laki & 32 & 55.6 \\
Perempuan & 40 & 44,4 \\
Total & 72 & 100 \\
\hline
\end{tabular}

Dari table tersebut, diketahui bahwa siswa laki-laki $(55,6 \%)$ lebih banyak dibandingkan siswa perempuan $(44,4 \%)$

Untuk sebaran subjek berdasarkan tingkat/ kelas diketahui sebagai berikut :

Tabel 2. Deskripsi Siswa Berdasarkan Kelas

\begin{tabular}{ccc}
\hline & Frekuensi & Presentase \\
\hline Kelas 4 & 21 & 29,2 \\
Kelas 5 & 25 & 34,7 \\
Kelas 6 & 26 & 36,1 \\
Total & 72 & 100 \\
\hline
\end{tabular}

Dari tabel tersebut diketahui, sebagian besar dari kelas 6 dengan sebaran 29,2\% kelas 4, 34,7\% kelas 5 dan $36,1 \%$ kelas 6 .

Berikutnya adaah deskripsi data dari masing-masing variabel, sebagai berikut:

Tabel 3. Deskripsi Data

\begin{tabular}{lcccccc}
\hline & N & Range & Min & Max & Mean & Std.Deviation \\
\hline Academic Burnout & 72 & 16 & 23 & 39 & 30,00 & 3,108 \\
Self-concept & 72 & 17 & 23 & 40 & 32.11 & 3,531 \\
Family Support & 72 & 17 & 19 & 36 & 25,53 & 3,361 \\
\hline
\end{tabular}

Dari tabel tersebut diketahui: sebaran skor academic burnout siswa dengan rata-rata 30, nilai terendah 23, tertinggi 39. Skor self-concept dengan rata-rata 32,11, nilai terendah 23, dan tertinggi 39. Skor family support dengan rata-rata 26,53 nilai terendah 19, tertinggi 36.

Uji normalitas dilakukan untuk mengetahu apakah data terdistribusi secara normal atau tidak. Hasil uji normalitas sebagai berikut:

Tabel 4. Hasil Uji Normalitas

\begin{tabular}{llc}
\hline Sujek Penelitian & & 37 \\
\hline Parameter Normal & Rata-Rata & 0,000 \\
& Std. Deviasi & 2,953 \\
& Absolut & 0,054 \\
& Positif & 0,054 \\
& Negatif &,- 047 \\
Test Statistic & &, 054 \\
Asymp.Sog. (2-tailed) & & 0,200 \\
\hline
\end{tabular}

Dari hasil tersebut diatas diketahui hasil signifikansi yang diperoleh sebesar 0,200 $(0,200>0,05$. Hal ini menujukkan bahwa data berdistribusi normal.

Dalam rangka mengetahui apakah variabel dependent (X1 dan X2) dan variabel independent $(\mathrm{Y})$ 
mempunyai hubungan yang linier, dilakukan uji linieritas, dengan hasil sebagai berikut:

Tabel 5. Hasil Uji Linieritas

\begin{tabular}{|c|c|c|c|}
\hline & & $\mathrm{F}$ & Sig \\
\hline \multirow[t]{3}{*}{$\begin{array}{l}\text { Academic Burnout*Self } \\
\text { concept }\end{array}$} & $\begin{array}{l}\text { Between group } \\
\text { combined }\end{array}$ & 1,608 & ,098 \\
\hline & Linierity & 6,261 & ,015 \\
\hline & Deviation for liniearity & 1,298 & ,235 \\
\hline & & $\mathrm{F}$ & Sig \\
\hline \multirow[t]{3}{*}{$\begin{array}{l}\text { Academic Burnout*Self } \\
\text { concept }\end{array}$} & $\begin{array}{l}\text { Between group } \\
\text { combined }\end{array}$ & 1,211 & 291 \\
\hline & Linierity & 2,605 & ,112 \\
\hline & Deviation for liniearity & 1,112 & ,368 \\
\hline
\end{tabular}

Dari tabel diatas diketahui bahwa terdapat hubungan yang linier sebesar 0,235 antara variabel academic burnout dengan self-efficacy. Pada Academic burnout dengan family support diketahui terdapat hubungan yang linier dengan nilai 0,368 .

Berdasarkan hasil uji prasyarat tersebut, diketahui bahwa data pada variabel self-concept, family support dan academic burnout berdistribusi normal dan juga diketahui bahwa hubungannya inier. Selanjutnya dilakukan uji hipotesis.

Uji hipotesis dengan pearson product moment dilakukan untuk menguji: (1) hubungan antara variabel X1 (self-concept) dengan variabel Y (academic burnout), (2) hubungan antara variabel X2 (family support) dengan Y (academic burnout), dan (3) hubungan anatara variabel X1 (self-concept) dan variabel X2 (Family support) dengan variabel Y (academic burnout) secara bersama-sama.

Uji hipotesis 1 dan 2 dilakukan untuk menguji hubungan variabel X1 (self-concept) dengan variabel $\mathrm{Y}$ (academic burnout) secara parsial, dan menguji hubungan variabel X2 (family support) dengan variabel Y (academic burnout) secara parsial, diketahui sebagai berikut:

Tabel 6. Hasil Uji Hipotesis

Correlations

\begin{tabular}{llrrr}
\hline & & Academic Burnout & Self-concept & Family Support \\
\hline \multirow{2}{*}{ Pearson Correlation } & Academic Burnout & 1.000 & .278 & .187 \\
& Self-concept & -2.278 & 1.000 & 2.174 \\
\multirow{4}{*}{ Sig. (1-tailed) } & Family Support & -4.187 & .174 & 1.000 \\
& Academic Burnout &. & .009 & .047 \\
& Self-concept & .009 &. & .042 \\
$\mathrm{~N}$ & Family Support & .007 & .072 &. \\
& Academic Burnout & 72 & 72 & 72 \\
& Self-concept & 72 & 72 & 72 \\
& Family Support & 72 & 72 & 72 \\
\hline
\end{tabular}

1. Korelasi antara Self-concept dengan Academic Burnout

Hasil korelasi pada tabel di atas, diketahui sebesar -2,278, dengan signifikansi $0.009(<0,05)$ dan korelasi bernilai negatif sebesar $(-2,278)>\mathrm{r}$ tabel $(2,000)$ maka dapat hipotesis diterima, artinya terdapat hubungan yang signifikan antara self-concept dengan academic burnout.

2. Korelasi antara Family Support dengan Academic Burnout

Hasil korelasi pada tabel di atas, diketahui sebesar -4.187, dengan signifikansi 0.007. Nilai $0.007<$ 0,05 dan korelasi bernilai negatif sebesar $(-4.187)>\mathrm{r}$ tabel $(2,000)$ maka dapat hipotesis diterima, artinya terdapat hubungan yang signifikan antara family support dengan academic burnout. 
3. Korelasi antara Self Concept dan Family Support dengan Academic Burnout

Untuk menguji Hipotesi 3 tentang hubungan antara variabel X1 (self-concept) dan X2 (family support) dengan variabel Y (academic burnout) secara simultan, sebagai berikut:

Tabel 7 Model Summary

Model Summary ${ }^{\mathrm{b}}$

Std. Error of the

\begin{tabular}{lrrrrr} 
Model & R & R Square & Adjusted R Square & Estimate & Durbin-Watson \\
\hline 1 & $.312^{\mathrm{a}}$ & .097 & .071 & 2.996 & 2.020 \\
\hline
\end{tabular}

a. Predictors: (Constant), Family Support, Self-concept

b. Dependent Variable: Academic Burnout

Nilai R square (koefisien detrminasi) pada tabel summary diatas diketahui sebesar 0.097. Hal ini menunjukan bahwa 9,7\% variabel academic burnout dipengaruhi oleh variabel self-concept dan family support, dan diketahui bahwa 90,3\% dipengaruhi oleh variabel lainnya.

Tabel 8. Hasil Uji Anova

\begin{tabular}{llrrrrr}
\multicolumn{7}{c}{ ANOVA $^{\mathrm{a}}$} \\
Model & \multicolumn{1}{c}{ Sum of Squares } & df & Mean Square & \multicolumn{1}{c}{ F } & \multicolumn{1}{c}{ Sig. } \\
\hline 1 & Regression & 349.720 & 2 & 524.801 & 46.237 & $.007^{\mathrm{b}}$ \\
& Residual & 533.225 & 69 & 7.728 & & \\
& Total & 882.944 & 71 & & & \\
\hline
\end{tabular}

a. Dependent Variable: Academic Burnout

b. Predictors: (Constant), Family Support, Self-concept

Dari tabel ANOVA di atas, diketahui bahwa nilai F hitung $=46.237>$ F table, dengan Signifikansi sebesar $0.007<0,05$. Model regresi yang diperoleh akan dapat digunakan dalam memprediksi academic burnout, serta dapat ditarik kesimpulan bahwa variabel self-concept (X1) dan family support (X2) secara bersama-sama (stimultant) memiliki hubungan dengan academic burnout $(\mathrm{Y})$.

Tabel 9. Hasil Coefficients Coefficients ${ }^{a}$

\begin{tabular}{|c|c|c|c|c|c|c|}
\hline \multirow{2}{*}{\multicolumn{2}{|c|}{ Model }} & \multicolumn{2}{|c|}{$\begin{array}{c}\text { Unstandardized } \\
\text { Coefficients }\end{array}$} & \multirow{2}{*}{$\begin{array}{c}\text { Standardized } \\
\text { Coefficients } \\
\text { Beta }\end{array}$} & \multirow[b]{2}{*}{$\mathrm{T}$} & \multirow[b]{2}{*}{ Sig. } \\
\hline & & B & Std. Error & & & \\
\hline 1 & (Constant) & 38.834 & 3.971 & & 4.865 & .000 \\
\hline & Self-concept & -.442 & .102 & .254 & 2.183 & .032 \\
\hline & Family Support & -.878 & .107 & .143 & 2.233 & .022 \\
\hline
\end{tabular}

a. Dependent Variable: Academic Burnout

Dari tabel diatas diperoleh model regresi berikut:

$$
\mathrm{Y}=38,834-0,442 \mathrm{X} 1-0,878 \mathrm{X} 2
$$

Dari persamaan tersebut diketahui bahwa setiap penambahan variabel bebas (X) dapat menurunkan tingkat variabel terikat $(\mathrm{Y})$. Setiap adanya peningkatan pada variabel bebas X1 (self concept), maka akan menurunkan variabel terikat Y (academic burnout) sebesar 0,442. Setiap peningkatan variabel bebas X2 (family support) akan menurunkan variabel terikat Y (academic burnout) sebesar 0,878 .

\section{Pembahasan}

Dari hasil uji hipotesis tentang pengaruh self-concept terhadap academic burnout dapat diketahui dari hasil korelasi sebesar -2.278, signifikansi sebesar 0.009. Nilai $0.009<0,05$ dan $\mathrm{r}$ hitung bernilai 
negatif sebesar $(-2,278)>\mathrm{r}$ tabel $(2,000)$ maka dapat dikatakan hipotesis diterima, artinya terdapat hubungan yang signifikan antara self-concept dengan academic burnout. Korelasi yang negative, menunjukkan bahwa semakin positif self-concept yang dimiliki siswa maka akan semakin rendah potensi siswa mengalami academic burnout dan semakin negatif self-concept pada siswa maka semakin tinggi potensi siswa mengalami academic burnout.

Hasil penelitian ini sejalan dengan hasil penelitian Wang (2019), yang menunjukkan bahwa selfconcept berpengaruh negatif terhadap academic burnout. Seseorang dengan self-concept yang positif akan cenderung percaya diri, memiliki penghargaan diri yang cenderung tinggi, yang akan akan mempengaruhi kepuasan kerja sehingga semakin meningkat serta memungkinkan individu tersebut lebih produktif, mampu menurunkan stres dan burnout. Individu dengan self-concept mempunyai penilaian yang baik tentang dirinya, sehingga ia tahu akan kemampuannya dan cenderung merespon positif setiap beban yang dihadapi, ditunjang kepercayaan diri dan harga diri yang tinggi. Individu dengan self-concept positif cenderung terhindar dari academic burnout (Puspasari, 2007). Sebaliknya, seseorang yang memiliki selfconcept yang negatif cenderung rentan mengalami academic burnout, kepercayaan diri dan harga dirinya cenderung rendah, sehingga ketika dihadapkan pada permasalahan, ia cenderung merasa pasrah, tidak mengevaluasi atau kurang efektif dalam mengembangkan pemecahan masalah.

Konsep diri yang positif adalah salah satu hal penting yang harus dimiliki seseorang karena dapat mengarahkan dan menunjang keberhasilan seseorang dalam mengembangkan perilaku ketika ia dihadapkan dalam berbagai situasi (Shavelson dalam Meilaratri \& Zulkarnai: 2004). Dengan konsep diri yang positif, maka siswa akan dapat menghadapi tantangan termasuk kondisi pembelajaran daring di masa pandemic ini sehingga terhindari dari academic burnout.

Dari hasil korelasi antara family support dengan academic burnout dapat diketahui korelasi sebesar -4.187, dengan nilai signifikansi 0.007. Nilai $0.007<0,05$ dan $r$ hitung bernilai negatif sebesar $(-4.187)>r$ tabel $(2,000)$ maka dapat dikatakan hipotesis diterima. Hal ini berarti bahwa terdapat hubungan antara family support dengan academic burnout. Korelasi yang negative, menunjukkan bahwa semakin positif family support yang dimiliki siswa maka akan semakin rendah potensi siswa mengalami academic burnout dan semakin negatif family support pada siswa maka semakin tinggi potensi siswa mengalami academic burnout.

Hasil penelitian ini sejalan dengan penelitian yang dilakukan Andi, dkk (2020), yang menunjukkan bahwa dukungan sosial (family support) diketahui berpengaruh terhadap academic burnout pada mahasiswa dengan pengaruh yang bersifat negative. Hal ini berarti bahwa semakin tinggi dukungan dari keluarga maka tingkat burnout mahasiswa akan cenderung menurun, demikian pula sebaliknya.

Pada masa pandemi ini, dalam pembelajaran daring, peran keluarga sangat penting, karena aktivitas belajar dialihkan di dirumah, sehingga orangtua juga berperan sebagai guru dan pengawas bagi anaknya (Sari, 2020). Dukungan keluarga merupakan bagian dari dukungan social. Dukungan sosial ditandai adanya keterlibatan dari orang lain yang membuat individu merasa nyaman, merasa diperhatikan dan dihargai (Sarafino dalam Mahmudi, 2014).

Ketika keluarga menunjukkan kepedulian, selalu memberikan dukungan pada siswa, memberikan apresiasi atas prestasi yang diperoleh siswa, maka akan semakin rendah kecenderungan siswa mengalami academic burnout (Agustin,2009). Sebaliknya, ketika keluarga utamanya orangtua cenderung kurang peduli pada siswa, maka akan dapat meningkatkan kemungkinan siswa mengalami academic burnout (Hawari dalam Fitrotin: 2017).

Dukungan keluarga membuat siswa merasa nyaman dan lebih bersemangat dalam belajar. Menurut Kurnia (2021), motivasi dan penguatan dari orangtua selama siswa belajar dirumah, pemenuhan sarana/ fasilitas belajar secara memadai perlu dilakukan orangtua agar siswa merasa nyaman dan bersemangat dalam belajar, termasuk kegiatan belajar dirumah (Kurnia, 2021).

Dari hasil uji hipotesis 3 diketahui bahwa variabel X1 (self-concept) dan X2 (family support) dengan $\mathrm{Y}$ (academic burnout) diketahui bahwa terdapat hubungan antara self concept dan family support dengan academic burnout secara stimultant (bersama-sama). Di dukung dengan hasil dari uji regresi berganda dimana nilai F hitung sebesar 46.237> Ftabel. dengan signifikansi sebesar $0.007<0,05$. Maka untuk memprediksi academic burnout dapat menggunakan model regresi yang diperoleh.

Hasil penelitian ini, sejalan dengan penelitian Habibah, Nirwana \& Afdal (2018) tentang burnout pada konselor. Dari penelitian ini diketahui bahwa dukungan sosial rekan kerja dan konsep diri sosial berpengaruh secar simultan terhadap burnout pada konselor dengan nilai kontribusi 55,7\%. Penelitian ini juga sejalan dengan penelitian Ikbar (2019) yang menunjukkan korelasi negative dan signifikan antara 
konsep diri dan dukungan sosial dengan burnout pada mahasiswa asisten pada Mata Kuliah Praktikum di Fakultas Psikologi Universitas Muhammadiyah Surakarta.

Dari hasil penelitian ini diketahui bahwa, siswa yang memiliki self-concept yang positif dan mendapat dukungan yang memadai dari keluarga, akan cenderung dapat menghindari academic burnout. Sebagaiman disampaikan oleh Sarafino (dalam Mahmudi: 2014), dukungan sosial yang ditandai dengan adanya keterlibatan orang lain secara positif, yang membuat individu merasa nyaman, merasa diperhatikan dan dihargai. Ketika siswa mendapatkan dukungan dari keluarga, ia mendapatkan bantuan sehingga merasa nyaman, diperhatikan dan dihargai, maka akan menujang self-conceptnya menjadi positif. Individu dengan self-concept yang positif akan lebih percaya diri, memiliki penilian yang baik tentang dirinya, tahu akan kemampuannya, yang mendukungnya dalam merespon positif setiap tantangan. Sehingga, dengan self-concept positif, siswa cenderung terhindar dari academic burnout (Puspasari, 2007).

Maslach, Schaufeli, \& Leiter (2001) menyebutkan 2 faktor yang dapat mempengaruhi terjadinya academic burnout, yaitu faktor situasional (eksternal) dan faktor individual (internal). Sebagai bagian dari faktor internal dan faktor eksternal, self-concept dan family support diketahui secara bersama-sama menguatkan siswa untuk dapat menghindari academic burnout.

\section{Kesimpulan}

Dari hasil penelitian ini, dapat disimpulkan beberapa hal. Hipotesis pertama diterima, self-concept secara signifikan berhubungan negative dengan academic burnout. Hipotesis kedua diterima, Family support secara signifikan berhubungan negative dengan academic burnout. Hipotesis ketiga diterima, selfconcept dan family support secara signifikan berhubungan negative dengan academic burnout.

\section{Daftar Pustaka}

Agustin, M. (2009) Model Konseling Kognitif-Perilaku untuk Menangani Kejenuhan Belajar Mahasiswa (Studi Pengembangan Model Konseling pada Mahasiswa Universitas Pendidikan Indonesia Tahun Akademik 2008/2009). Universitas Pendidikan Indonesia.

Anggriana T.M., Silvia Y. W., \& Tita M.M. (2014). Job Performance Ditinjau Dari Konflik Peran Ganda, Burnout Dan Family support Kerluarga. Jurnal LPPM, 2 (2).

Asrowi, Agus, Agit (2020). Academic Burnout Pada Peserta Didik Terdampak Pandemi Covid-19. Jurnal Bimbingan dan Konseling, 5(1).

Azwar, S. 2003. Dasar-Dasar Psikometri . Yogyakarta: Pustaka Pelajar.

Christiana E., (2020). Burnout Akademik Selama Pandemi Covid 19. Prosiding Bimbingan Dan Konseling.

Dimala C.P.,\& Nita R. (2019). Kontribusi Academic Burnout Dan Family support Terhadap Academic Engagement Pada Mahasiswa Unversitas Buana Perjuangan Karawang. Jurnal Psikologi.

Fitrotin, K. 2017. Hubungan Antara Motivasi Berprestasi dan Dukungan Sosial Orang tua dengan Kejenuhan Belajar Siswa. Universitas Muhammadiyah Surakarta.

Habibah, Suci., Nirwana, Herman., \& Afdal, Afdal., (2018), Contribution of Social Support co-workers and Social Self Concept to Condition of School Counselor Burnout, Proceedings International Conferences on Educational, Social Sciences and Technology (ICESST), Fakultas Ilmu Pendidikan UNP.

Ikbar, Ridho Roqwan, (2019), Hubungan Konsep Diri dan Dukungan Sosial dengan Burnout pada Asisten Mata Kuliah Praktikum Fakultas Psikologi Universitas Muhammadiyah Surakarta, Skripsi, Fakultas Psikologi Universitas Muhammadiyah Surakarta

Kim, B., Jee, S., Lee, J., An, S., \& Lee, S.M. (2018). Relationships between social support and student burnout: Ameta-analytic approach. Wiley Journal. 34(1).

Kurnia, D. (2021). Dinamika Gejala Kejenuhan Belajar Siswa Pada Proses Belajar Online Faktor Faktor Yang Melatarbelakangi Dan Implikasinya Pada Layanan Bimbingan Keluarga. Jurnal Inovasi Keguruan dan Ilmu Pendidikan, 1(1).

Lin S.H \& Yun C.H. (2014). Life Stress And Academic Burnout. Active Learning in Higher Education, $15(1)$.

Maslach C., Leiter, \& Kelly. (1997). The Truth About Burnout: How Organizations Cause Personal Stress and What to Do About It. San Fransisco: Jossey-Bass. 
Meilaratri, B., \& Zulkarnain. (2004). Konsep diri dan kecenderungan pengambilan keputusan dalam membeli pakaian pada remaja wanita. Insight, 2, (1), 10-16.

Papalia, D. E., Olds, S., W., \& Feldman, R. D. (2007), Human Developmen (10 th ed.), New York: Mc Grow Hill

Purwanto A., Rudi P., Priyono B.S., Laksmi M.W.,Choi C.H., Ratna S.P. (2020). Studi Eksploratif Dampak Pandemi COVID-19 Terhadap Proses Pembelajaran Online di Sekolah Dasar. Journal of Education, 2(1).

Rahmati, Z. (2014). The Study of Academic Burnout In Students with High and Low Level Of Self Efficacy. Social and Behavioral Sciences, $p 51$.

Sari, T. T (2020). Self-efficacy Dan Dukungan Keluarga Dalam Keberhasilan Belajar Dari Rumah Di Masa Pandemi Covid-19. Journal Education Research and Development, 4(2).

Schaufeli, W. B. (2002). Burnout And Engagement In University Students : A Cross-National Study. Journal Of Cross $^{-}$Cultural Psycholog, 33(5).

Sugiarto, W., Sri. M., M Rajab. 2019. Hubungan Lingkungan Kerja dan Konsep Diri dengan Burnout. Universitas Medan Area. Proceeding Icopoid (148-157).

Tsigilis, N., Zournatzi, E., \& Koustelios, A. (2011). Kelelahan di antara pendidikan jasmani guru di sekolah dasar dan menengah. Jurnal Internasional Humaniora dan Ilmu Sosial, 1(7).

Turner, H.A. et al. (2015). Effects of Poly-Victimization on Adolescent Social Support, Self-Concept, and Psychological Distress. Journal of Interpersonal Violence. 1-26.

Wang M., Hui G., Yuanzhen L., Caixia X., Bei R., (2009). Academic Burnout And Professional Self-concept of Nursing Students: A Cross-sectional Study. International Journal for Health Care Education.

Yang H. J. (2004). Factors Affecting Student Burnout and Academic Achievement In Multiple Enrollment Programs In Taiwan's Technical-vocational Colleges. International Journal of Education Development, 24(283-301). 